\title{
EVALUATION IMPLEMENTATION OF CURRICULUM UNIT LEVEL OF EDUCATION FOR ARABIC LENGUAGE LEARNING IN MTS DDI SEPPANGE
}

\author{
St. Jumaeda \\ FITK Institut Agama Islam Negeri (IAIN) Ambon \\ edha amel77@yahoo.com
}

\begin{abstract}
The purpose of this study is to obtain objective information and the find improvement quality process and quality output on Arabic Lenguage program. This study is an evaluative research approach using a model developed by Widoyoko, which includes two main components, namely: the quality of the process and instructional output. In this study applied studies the evaluation program, method the collection of data obtained through the study of documents, interviews, questionnaires and observation. The evaluation of the assessments made at each stage of evaluation, and decision making. The finding in that Arabic Lenguage learning program evaluation in MTs DDI Seppange, shows that the quality of the process of learning programs, including the categories of good, and the output quality of learning of Arabic Lenguage are also included in the good category. Considering these facts before, there are still some aspects in the evaluation process quality and output quality of learning that needs to be improved so that the learning of Arabic Lenguage will be more effective and achieve competence that has been planned.
\end{abstract}

Key words: evaluation, learning of Arabic Lenguage 
Abstrak: Tujuan dari penelitian ini adalah untuk memperoleh informasi yang objektif tentang peningkatan kualitas proses dan kualitas output pada program pembelajaran Bahasa Arab. Penelitian ini adalah suatu pendekatan penelitian evaluatif dengan menggunakan model yang dikembangkan oleh Widoyoko, yang mencakup dua komponen utama, yaitu: kualitas proses dan kualitas output pembelajaran. Dalam penelitian ini diterapkan metode studi evauasi Program, pengumpulan data diperoleh melalui studi dokumen, wawancara, kuesioner dan observasi. Temuan dalam evaluasi program pembelajaran Bahasa Arab di MTs DDI Seppange, menunjukkan bahwa kualitas dari proses program pembelajaran, termasuk kategori baik, dan kualitas output pembelajaran Bahasa Arab juga termasuk dalam kategori baik, meskipun terdapat beberapa aspek dalam evaluasi kualitas proses dan kualitas output pembelajaran yang perlu ditingkatkan sehingga pembelajaran Bahasa Arab akan lebih efektif dan mencapai kompetensi yang telah direncanakan.

Kata Kunci: evaluasi, pembelajaran Bahasa Arab.

\section{PENDAHULUAN}

Salah satu faktor utama pendukung keberhasilan pembangunan di suatu Negara adalah tersedianya Sumber Daya Manusia (SDM) yang berkualitas. Usaha peningkatan kemampuan dan kualitas sumber daya manusia merupakan tantangan utama yang sedang dihadapi bangsa Indonesia saat ini dan di masa depan

Berbagai upaya dalam peningkatan kualitas sumber daya manusia di Indonesia telah dilakukan oleh pemerintah diantaranya dengan melalui pelaksanaan pendidikan, namun praktek pendidikan di Indonesia selama ini kurang mampu menghasilkan sumber daya manusia yang memiliki keunggulan kompetitif di dunia persaingan global. Menyadari rendahnya mutu dan kualitas pendidikan sebagai salah satu penyebab lemahnya kualitas sumber daya manusia dalam mendukung pembangunan nasional, maka 
pemerintah telah melakukan berbagai upaya dalam usaha peningkatan kualitas sumber daya manusia. Upaya tersebut diantaranya dengan melalui lembaga pendidikan, yang sekaligus disertai dengan peningkatkan mutu dan kualitas pendidikan itu sendiri. Esensi pendidikan yang berkualitas khususnya dalam penelitian ini diasumsikan sebagai proses pendidikan yang berkualitas sehingga dapat menghasilkan output atau dengan kata lain menghasilkan lulusan yang sesuai dengan harapan masyarakat, baik dalam kualitas moral, pengetahuan, maupun kompetensi kerja sebagai syarat mutlak dalam kehidupan masyarakat global yang terus menerus berkembang saat ini, dan yang akan datang.

Belajar dari sejarah tentang bagaimana hasil pendidikan nasional sejak satu abad kebangkitan nasional pertama yang lalu, ternyata persoalan pendidikan bukan hanya menyangkut peserta didik sebagai subjek namun juga menyangkut masalah fisik seperti gedung, sarana prasarana, kurikulum, dan lain sebagainya. Dalam upaya mengatasi persoalan pendidikan tersebut penyelenggaraan pendidikan nasional yang selama ini disorot mengalami kemunduran, sebenarnya telah mengalami banyak perubahan, di antaranya keinginan untuk mengajukan KTSP sebagai pengganti Kurikulum Berbasis Kompetensi (KBK).

Perubahan atau penggatian kurikulum tersebut didasari bahwa disatu sisi, merupakan perubahan dan perkembangan disegala aspek kehidupan perlu direspon oleh kinerja pendidikan yang profesional dan bermutu tinggi. Mutu pendidikan yang demikian itu sangat diperlukan untuk mendukung terciptanya manusia yang cerdas dan berkehidupan yang damai, terbuka, dan berdemokrasi, serta mampu bersaing secara terbuka di era global, sehingga dapat meningkatkan kesejahteraan seluruh warga negara Indonesia. Dalam pada itu, kinerja pendidikan menuntut adanya pembenahan dan penyempurnaan terhadap aspek substantif yang mendukungnya, yakni kurikulum. Pada sisi lain perubahan kurikulum juga didasari pada kesadaran 
bahwa perkembangan dan perubahan yang terjadi dalam kehidupan bermasyarakat, berbangsa dan bernegara di Indonesia tidak terlepas dari pengaruh perubahan global, perkembangan ilmu pengetahuan dan teknologi, serta seni dan budaya. Hasibuan mengemukakan bahwa:Kurikulum sebagai suatu produk pemikiran sudah barang tentu tidak mungkin dapat diberlakukan untuk sepanjang zaman. Kurikulum selalu mempunyai keterbatasan-keterbatasan menurut ukuran ruang dan waktu ketika kurikulum tersebut dimunculkan atau diberlakukan (Hasibuan, 2010: 15). Oleh sebab itu terkait dengan pendapat tersebut di atas, maka perubahan global secara terus menerus yang terjadi saat ini menuntut perlunya perbaikan sistem pendidikan nasional termasuk penyempurnaan kurikulum selaku pedoman, acuan atau rujukan penyelenggaraan pendidikan dengan melalui pembelajaran, sehingga pendidikan nantinya diharapkan dapat mewujudkan masyarakat yang mampu bersaing dan menyesuaikan diri dengan perubahan zaman.

Kurikulum digunakan sebagai pedoman dalam penyelenggaraan kegiatan pembelajaran untuk mencapai tujuan pendidikan yang telah ditentukan. Guna mewujudkan kurikulum yang sesuai dengan tuntutan dan kebutuhan masyarakat, mengantisipasi perkembangan zaman, serta memberikan guideline atau acuan bagi penyelenggaraan pembelajaran pada satuan pendidikan, maka idealnya kurikulum senantiasa direvisi guna penyesuaian dan perbaikan menuju yang lebih baik serta penyesuaian dengan tuntutan zaman yang selalu berubah.

Revisi kurikulum untuk perbaikan acuan penyelenggaraan pendidikan telah dilakukan pemerintah dengan menerbitkan Peraturan Pemerintah No. 19 tahun 2005 tentang Standar Nasional Pendidikan. Didalam Peraturan Pemerintah Republik Indonesia Nomor 19 tahun 2005 tentang Standar Nasional Pendidikan, mengamanatkan Kurikulum Tingkat Satuan Pendidikan (KTSP) jenjang pendidikan dasar dan menengah disusun oleh satuan 
pendidikan dengan mengacu kepada Standar Isi (SI) dan Standar Kompetensi Lulusan (SKL) serta berpedoman pada panduan yang disusun oleh Badan Standar Nasional Pendidikan (BSNP).

Implementasi KTSP menyebabkan terjadinya Pergeseran paradigma dalam pranata pendidikan yang semula terpusat menjadi desentralistis telah membawa konsekuensi dalam pengelolaan pendidikan, termasuk di Madrasah. Kebijakan tersebut dapat dimaknai sebagai pemberian otonomi yang seluas-luasnya dalam mengelolah madrasah, termasuk di dalamnya berinovasi dalam pengembangan kurikulum dan model-model pembelajaran.

Kebijakan implementasi KTSP dan pemberian otonomi pendidikan juga diharapkan melahirkan organisasi madrasah yang sehat serta terciptanya daya saing madrasah. Sejalan dengan perkembangan teknologi informasi dan pembelajaran berbasis teknologi informasi yang sangat pesat, hendaknya MTs DDI Seppange menyikapinya secara saksama, diantaranya melalui peningkatan kualitas proses dan kualitas output pembelajaran agar apa yang dicita-citakan dalam perubahan paradigma pendidikan dapat segera terwujud.

Pemberian otonomi tersebut hendaknya diimbangi dengan perubahan yang berorientasi kepada kinerja dan partisipasi secara menyeluruh dari komponen pendidikan yang terkait. Kondisi ini senada/sejalan dengan perubahan kurikulum yang sedang diluncurkan dewasa ini oleh pemerintah, yakni kurikulum tingkat satuan pendidikan (KTSP). Konsekwensi yang harus ditanggung oleh madrasah, tak terkecuali MTs DDI Seppange adalah restrukturisasi dalam pengelolaan madrasah (capacity building), profesionalisme guru, penyiapan infrastruktur, kesiapan siswa dalam proses belajar dan iklim akademik madrasah.

Pada MTs DDI Seppange, restrukturisasi dalam pengelolaan madrasah terutama ditekankan pada hal-hal yang menyangkut peningkatan kualitas proses dan kualitas output pembelajaran. Upaya tersebut diwujudkan 
melalui penyusunan visi misi dan tujuan MTs DDI Seppange yang dimuat dalam KTSP yang kemudian akan digunakan sebagai acuan atau pedoman dalam penyelenggaraan program pembelajaran, dimana ditekankan pada usaha untuk mewujudkan siswa yang berakidah dan bersyari'ah islam sempurna serta berahlak mulia, mewujudkan siswa yang unggul dalam penguasaaan iptek dan pengamalan imtaq, dan mewujudkan siswa yang diterima dan dibutuhkan diberbagai lapisan masyarakat. Sejalan dengan maksud tersebut maka peningkatan kualitas proses dan kualitas output pembelajaran dengan menggunakan KTSP sebagai pedoman atau acuan sebaiknya dapat dimplementasikan pada pelaksanaan program pembelajaran di MTs DDI Seppange, termasuk pada pelaksanaan program pembelajaran Bahasa Arab.

Untuk melihat tingkat pencapaian mutu dan tujuan pendidikan, terutama kualitas proses dan kualitas output pembelajaran, diperlukan suatu bentuk evaluasi. Evaluasi dilakukan dalam rangka pengendalian mutu pendidikan secara nasional sebagai bentuk akuntabilitas penyelenggara pendidikan kepada pihak-pihak yang berkepentingan, diantaranya terhadap peserta didik, lembaga, dan program pendidikan. (Sukardi, 2009: 1)

Berbagai upaya telah dilakukan dalam usaha mencapai peningkatan kualitas proses dan kualitas output pembelajaran yang dilaksanakan di MTs DDI Seppange. Khusus peningkatan kualitas proses dan kualitas output pembelajaran Bahasa Arab sangat ditentukan oleh tiga unsur, yaitu: guru, siswa, dan kurikulum. Ketiga unsur tersebut dapat diasumsikan bahwa (1) Guru, sesuai dengan fungsinya bertugas mengoptimalkan kemampuan siswa dalam belajar atau sering diistilahkan dengan mengajar. Dalam mengoptimalkan kemampuan siswa profesionalisme, kemampuan dan pemahaman guru yang memadai dalam mengajar sangat menentukan peningkatan kualitas pembelajaran sekaligus keberhasilan program pembelajaran mencapai tujuan sebagaimana telah direncanakan di dalam 
silabus yang telah disusun sebelumnya, (2) Siswa, dengan segala karakteristiknya dalam proses pembelajaran diharapkan secara maksimal dapat mencapai tujuan belajar. Karakteristik siswa yang dimaksud khususnya dalam penelitian ini diantaranya menyangkut derajat afeksi atau sikap siswa, motivasi, personal skill, dan social skill yang dapat dioptimalkan untuk meningkatkan kualitas maupun output pembelajaran, dan (3) Kurikulum, adalah merupakan pedoman atau media serta sekaligus merupakan salah satu fasilitas penunjuang untuk mencapai tujuan yang diinginkan. Oleh karena itu, maka perlu dilakukan evaluasi pada unsur-unsur tersebut untuk mengidentifikasi kualitas proses dan kualitas output pembelajaran khususnya pada pelaksanaan program pembelajaran Bahasa Arab.

\section{METODE}

Penelitian evaluasi program ini menggunakan model kualitas proses dan kualitas output pembelajaran, maka penelitian ini mencakup berbagai aspek dan indikator yang terkait dengan komponen-komponen kualitas proses dan kualitas output program pembelajaran yang dievaluasi. Masingmasing aspek dari komponen-komponen evaluasi tersebut mempunyai bentuk dan sifat serta sumber data yang berbeda sehingga memerlukan penggunaan metode yang berbeda pula dalam hal pengumpulan data dan analisisnya.

Kegiatan evaluasi dilakukan melalui dua komponen utama (kualitas proses dan kualitas output) dengan menggunakan variasi teknik pada masing-masing komponen tersebut. Pilihan-pilihan teknik tersebut disesuaikan dengan jenis dan karakteristik data yang dibutuhkan serta dari sumber mana data dapat diperoleh. Pada tahap analisis data digunakan teknik analisis yang disesuaikan dengan jenis dan karakteristik data serta kepentingan analisis untuk menjawab pertanyaan evaluasi.

\section{HASIL}




\section{Komponen Kualitas Proses Pembelajaran.}

Untuk mengetahui tingkat efektifitas komponen kualitas proses pembelajaran tersebut, dapat dilakukan melalui evaluasi penilaian terhadap: (a) kinerja guru, (b) fasilitas pembelajaran, (c) iklim kelas, (d) sikap siswa, dan (e) motivasi belajar.

a. Kinerja guru

pemahaman karakteristik siswa nampak pada dukungan guru terhadap siswa yang memiliki pemahaman yang kurang dengan melalui pembelajaran individual dan untuk menghindari hal tersebut, maka dalam perencanaan program pembelajaran atau RPP disesuaikan dengan kondisi, kemampuan dan karakteristik siswa, hal tersebut sejalan dengan kriteria KTSP sebagai acuan dalam pelaksanaan program pembelajaran, dimana KTSP disusun dengan memperhatikan kondisi dan karakteristik daerah.

Mengenai perencanaan pembelajaran Bahasa Arab telah sesuai dengan Visi dan Misi Madrasah serta tujuan pembelajaran, karena telah menggunakan acuan KTSP yang disusun dengan memperhatikan kondisi dan karakteristik sekolah. Khusus dukungan fasilitas, sarana dan parasarana yang diperlukan cukup memadai, seperti tersedianya perpustakaan, laboratorium, lapangan olah raga dan seni yang dapat digunakan untuk mendukung pelaksanaan kegiatan program pembelajaran. Kegiatan program pembelajaran berlangsung dalam suatu proses yang sistimatis menurut model dan pendekatan yang digunakan dalam RPP, yang dimulai dari kegiatan awal, inti dan penutup. Langkah-langkah pembelajaran tersebut adalah seperti yang telah digariskan dalam rancangan RPP sebagai pedoman dalam pembelajaran. Dalam kegiatan pembelajaran guru kadankadang menggunakan media pembelajaran, hanya sesuai dengan relevansi materi yang dibawakan dalam kegiatan pembelajaran. 
Pada aspek penguasaan pengelolaan pembelajaran terkait dengan pemilihan dan pengorganisasian bahan pembelajaran serta penentuan bahan pengayaan dilakukan dengan tetap disesuaikan menurut kemampuan dan karakteristik peserta didik, sedangkan materi dengan waktu dan ruang lingkup urutan yang digunakan dalam pembelajaran cukup sesuai. Kemudian antara sumber dan media pembelajaran dengan kompetensi dasar dan materi pembelajaran sangat sesuai, demikian pula halnya antara sumber dan media pembelajaran sesuai dengan kemampuan peserta didik. Mengenai metode pembelajaran sangat sesuai dengan kompetensi dasar dan sesuai pula dengan materi standar dan alokasi waktu.

Penguasaan pengelolaan pembelajaran juga dibuktikan melalui pelaksanaan proses pembelajaran yang dimulai dari perencanaan, pelaksanaan dan penilaian seluruhnya telah menggunakan KTSP sebagai acuan atau pedomannya. Dalam melaksanaan pembelajaran guru cukup mampu dalam menentukan strategi pembelajaran yang akan digunakan untuk memenuhi apa yang dituntut dalam KTSP, termasuk mampu mengimplementasikan teknik dan strategi pengelolaan kelas, sehingga sekolah secara umum cukup kondusif dalam melaksanakan kegiatan pembelajaran.

Selanjutnya, pada aspek penguasaan strategi pembelajaran, strategi untuk meningkatkan sikap kedisiplinan siswa dalam mengikuti pembelajaran, maka dikembangkan menejemen dalam pengololaan madrasah dengan selalu menekankan pada disiplin dalam segala aktifitas pelaksanaan kegiatan pembelajaran yang dimuat dalam tata tertib sekolah. Hal tersebut diperjelas dengan adanya ketentuan bahwa apabila ada guru yang berhalangan hadir maka jamnya diisi oleh wali kelas atau guru piket, sehingga tidak ada kesempatan bagi siswa untuk tidak mengikuti kegiatan pembelajaran. Dalam kegiatan pembelajaran guru dapat membangun hubungan yang akrab dengan siswa, melalui pemberian ruang yang cukup pada siswa untuk 
mengembangkan kreasi dan ide-idenya, selanjutnya guru selalu memberikan dukungan jika ada kegiatan yang akan dilaksanakan oleh siswa, sepanjang kegiatan tersebut berkaitan dengan kegiatan pembelajaran, dan hubungan yang baik antara guru dan siswa tersebut tidak terbatas pada pembelajaran di kelas saja akan tetapi siswa tetap menghormati guru meskipun diluar pembelajaran, bahkan ketika bertemu di luar jam sekolah.

Menyangkut aspek penguasaan strategi pembelajaran, khususnya terkait dengan strategi untuk meningkatkan partisipasi dan keterlibatan siswa dalam pembelajaran di dalam kelas dapat dilakukan dengan selalu memberikan kesempatan yang sama kepada siswa tanpa ada perbedaan antara satu sama lainnya untuk mengeluarkan pendapat, sedangkan di luar kegiatan pembelajaran dapat dilakukan dengan cara sering menyapa atau mengajak siswa untuk berdiskusi mengenai seputar pembelajaran. untuk menjelaskan materi pembelajaran, selain sumber yang disiapkan sekolah, guru juga menggunakan berbagai sumber lain yang relevan dengan materi pembelajaran, yang disajikan dengan selalu menggunakan setrategi secara bervariasi dan pada pelaksanaannya berusaha untuk selalu tepat waktu dalam memulai dan mengakhiri pembelajaran.

Seterusnya, guru selalu melaksanakan pembelajaran sesuai dengan kompetensi yang akan dicapai dan pembelajaran sering pula dilaksanakan secara sistematis serta secara kontekstual. Dalam pelaksanaan pembelajaran guru selalu menumbuhkan motivasi belajar siswa dan sering pula menumbuhkan partisipasi aktif siswa serta selalu memantau kemajuan belajar setiap siswa. Guru memiliki keterampilan yang cukup dalam menggunakan sumber belajar dan media pembelajaran, dimana dalam penggunaannya sering menghasilkan pesan yang menarik dan siswa sering dilibatkan dalam mendayagunakan media dan sumber belajar tersebut. Dalam pembelajaran guru cukup menguasai kelas, hal tersebut dapat dilakukan melalui cara misalnya sering menumbuhkan keceriaan dan 
antusiasme siswa dalam belajar. Guru selalu melaksanakan pembelajaran sesuai dengan alokasi waktu yang direncanakan dengan selalu menggunakan bahasa yang jelas dan mudah dipahami oleh siswa serta sering menggunakan bahasa tulis sesuai kaidah yang benar. Selanjutnya, pada pelaksanaan pembelajaran selalu dilakukan implementasi keagamaan. Mengenai aktifitas guru dalam membuat rangkuman pembelajaran tidak pernah dilakukan dengan melibatkan siswa. Khusus mengenai kemampuan melaksaakan penilaian, guru selalu melakukan penilaian/ refleksi terhadap kegiatan yang telah dilakukan dan sering melaksanakan tindak lanjut atas nilai hasil belajar yang diperoleh siswa setelah mengikuti pembelajaran. Pada akhir proses pelaksanaan pembelajaran guru selalu mengimformasikan materi yang akan dipelajari atau dibahas secara bersama pada pertemuan berikutnya dan selalu menutup pelaksanaan proses pembelajaran dengan mengajak siswa untuk mengucapkan salam dan do'a secara bersama-sama.

Pada aspek kemampuan melaksanakan penilaian, dapat diuraikan bahwa penilaian terhadap siswa dilakukan dengan obyektif dan adil, jadi nilai yang diberikan adalah benar-benar sesuai dengan kemampun yang dimiliki siswa, dengan tidak membeda-bedakan antara satu sama lainnya meskipun memiliki perbedaan Suku Agama Ras Golongan (SARG). Dengan demikian penilaian adalah benar-benar dapat mengukur kompetensi siswa terhadap mata pelajaran yang telah diajarkan. Selanjutnya, guru sering memberikan tugas-tugas untuk dikerjakan dan diselesaikan oleh siswa, minimal setiap selesai satu kompetensi dasar diberikan tugas untuk dikerjakan dan diselesaikan oleh siswa. Melalui tugas tersebut guru kemudian memberikan balikan (feedback) terhadap tugas-tugas yang dikerjakan siswa, dengan membahas secara bersama-sama dengan siswa misalnya dengan menanyakan kembali kepada siswa apa jawaban dari soal-soal yang telah diselesaikan. Hal tersebut dilakukan dengan menunjuk salah seorang siswa secara bergiliran untuk menjawabnya, selanjutnya dilakukan penilaian 
terhadap hasil belajar dengan melalui penilaian proses yang selalu dilakukan pada saat pembelajaran sedang berlangsung, sedangkan penilaian formatif pada pertengahan sumester dan penilaian sumatif pada akhir semester.

Evaluasi pada komponen kualitas proses pembelajaran menunjukkan hasil yang baik namun terdapat kelemahan utama pada beberapa aspek dari komponen kualitas proses pembelajaran, diantaranya; kinerja guru, melalui jawaban responden terhadap angket yang diberikan diketahui bahwa ternyata aspek yang perlu ditingkatkan, adalah: kurangnya penguasaan strategi pembelajaran yang dimiliki guru mata pelajaran. Berdasarkan hasil evaluasi, data yang diperoleh menurut penilaian responden belum mampu menggambarkan hasil yang lebih maksimal. Karena itu, perlu dilakukan penggunaan gaya mengajar yang lebih variatif, dengan cara demikian deskripsi penguasaan strategi pembelajaran akan menjadi lebih inovatif dan interaktif.

b. Fasilitas pembelajaran

Fasilitas pembelajaran, masih terdapat aspek-aspek yang perlu dilakukan peningkatan agar dapat mendukung penyelenggaraan program pembelajaran dengan baik, aspek-aspek tersebut, yaitu: aspek kondisi ruang pembelajaran menurut penilaian responden perlu diperbaiki terutama ketenangan dan kenyamanan ruang belajar, media pembelajaran belum sepenuhnya mencukupi serta tidak semua media pembelajaran dapat dipergunakan secara maksimal dan minimnya penggunaan media pembelajaran oleh guru mata pelajaran.

c. Iklim Kelas,

Terdapat beberapa aspek yang perlu ditingkatkan, agar aspek iklim kelas dapat menjadi lebih baik, sehingga penyelenggaraan program pembelajaran akan dapat berproses secara berkualitas yang pada akhirnya dapat menghasilkan output yang berkualitas pula. Berdasarkan hasil penilaian responden diketahui ternyata aspek-aspek yang perlu ditingkatkan, 
yaitu: pada aspek kekompakan siswa menurut penilaian responden perlu diperbaiki untuk lebih ditingkatkan, serta aspek keterlibatan siswa dan kepuasan siswa menurut reponden sebaikanya lebih ditingkatkan, karena itu siswa perlu diberikan kesempatan dan ruang yang cukup untuk berimpropisasi dalam program pembelajaran diantaranya dengan banyak melibatkan siswa dalam pelaksanaan proses pembelajaran.

\section{d. Sikap Siswa,}

Sikap siswa terhadap pemahaman manfaat, kecenderungan dan rasa senang, seperti pada kegiatan ekstrakurikuler. Kegiatan ekstrakuriuler yang diselenggarakan secara keseluruhan cukup relevan dalam mendukung kegiatan pembelajaran, karena dalam menentukan kegiatan yang akan ditetapkan harus memiliki hubungan dengan peningkatan prestasi, sehingga pembinaan tidak rumit dan disesuikan dengan minat dan bakat, sementara prestasi siswa pada kegiatan ekstrakurikuler, cukup baik karena sering menjadi pemenang baik pada ivent antar madrasah maupun besama dengan SMP pada tingkat local maupun daerah, dan prestasi tersebut sangat berpengaruh pada prestasi pembelajaran sepanjang siswa tersebut selalu konsisten.

Secara keseluruhan, skor yang diperoleh dari hasil penilaian responden terhadap komponen kualitas proses pembelajaran mencapai $79,50 \%$, berdasarkan kriteria yang digunakan pada penelitian ini, maka tingkat efektivitas komponen kualitas proses pembelajaran dalam pelaksanaan program pembelajaran Bahasa Arab di MTs DDI Seppange menurut responden termasuk pada kategori baik.

Komponen kualitas proses pembelajaran menitikberatkan pada kinerja guru yakni interaksi antara guru dan siswa yang terjadi dalam konteks ruang kelas tertentu dengan dukungan fasilitas pembelajaran tertentu. Pola interaksi antara guru dengan siswa akan menumbuhkan iklim kelas tertentu, sehingga kualitas proses pembelajaran akan tergantung pada prilaku guru 
dalam mengajar dikelas, fasilitas pembelajaran dan iklim kelas. Kinerja guru yang baik akan mempunyai pengaruh terhadap iklim kelas, sikap dan motivasi belajar siswa serta hasil belajar siswa, iklim kelas yang baik akan mempunyai pengaruh terhadap sikap dan motivasi siswa serta hasil belajar siswa. Sikap positif siswa dalam kegiatan pembelajaran akan mempunyai pengaruh terhadap motivasi belajar siswa yang akan berpengaruh terhadap keberhasilan belajar Bahasa Arab siswa.

Secara keseluruhan realitas yang ditemukan pada penelitian evaluasi kualitas proses program pembelajaran Bahasa Arab berkualitas baik, bahkan kinerja guru sangat baik berdasarkan criteria standar evaluasi, namun terdapat beberapa aspek yang kurang atau tidak memenuhi standar sehingga menurut peneliti, disimpulkan perlu dilakukan upaya peningkatan dan perbaikan pada aspek tersebut.

\section{Komponen Kualitas Output Pembelajaran.}

Untuk mengetahui tingkat efektifitas komponen kualitas output pembelajaran tersebut, dapat dilakukan melalui evaluasi penilaian terhadap: (a) kecakapan akademik, (b) kecakapan personal, dan (c) kecakapan sosial.

a. Kecakapan Akademik siswa,

Dalam pelaksanaan program pembelajaran Bahasa Arab pada MTs DDI Seppange, berdasarkan hasil evaluasi pada aspek tersebut diperoleh skor $85.56 \%$ dari skor maksimum yang berarti kecakapan akademik siswa menunjukkan bahwa kompetensi dasar yang dapat dikuasai atau dimiliki siswa setelah mengiuti kegiatan pembelajaran dinilai temasuk pada kategori sangat baik.

b. Kecakapan personal siswa

Dalam pelaksanaan program pembelajaran Bahasa Arab pada MTs DDI Seppange, berdasarkan hasil evaluasi pada aspek tersebut diperoleh rata-rata skor $80 \%$, yang berarti bahwa kecakapan memecahkan masalah 
yang tidak terlepas dari kecakakapan mengambil keputusan dari berbagai alternatif yang dapat digunakan untuk memecahkan masalah, dinilai dengan kategori baik

\section{c. Kecakapan Sosial}

Dalam pelaksanaan program pembelajaran Bahasa Arab pada MTs DDI Seppange, berdasarkan hasil evaluasi pada aspek tersebut diperoleh rata-rata skor $84.05 \%$, hal itu berarti bahwa, kecakapan bekerja sama dengan orang lain yang tidak terlepas dari kecakapan atau kemampuan untuk menjadi pemimpin yang terdapat pada siswa dan dinilai pada kategori baik.

Secara keseluruhan, tingkat efektivitas komponen kualitas output pembelajaran dalam pelaksanaan program pembelajaran Bahasa Arab di MTs DDI Seppange menurut responden termasuk pada kategori baik.

Komponen kualitas output pembelajaran menitikberatkan pada kecakapan akademik yakni penguasaan seperangkat konsep dasar yang bersumber dari berbagai disiplin ilmu yang disesuaikan dengan tingkat perkembangan psikologis siswa setelah mengikuti pembelajaran yang berpengaruh pada kecakapan personal yaitu kecakapan yang diperlukan agar siswa dapat eksis dan mampu mengambil peluang yang positif dalam kondisi kehidupan yang berubah dengan sangat cepat, sehingga pada akhirnya siswa memiliki kecakapan social yaitu kecakapan yang dibutuhkan untuk hidup (life skills) dalam masyarakat yang multi-kultur, masyarakat demokrasi dan masyarakat global yang penuh persaingan dan tantangan.

kecakapan akademik siswa mencapai rata-rata skor $85.60 \%$ yang berarti termasuk pada kategori sangat baik, demikian pula halnya dengan kemampuan yang dicapai siswa pada Kecakapan Personal siswa yang diperoleh 79,60\% dari skor maksimum yang berarti baik, serta hasil perolehan pada aspek Kecakapan Sosial siswa yang mencapai 83.58\%, yang dalam klasifikasi pada evaluasi ini termasuk pada kategori baik. Berdasarkan 
skor tersebut maka secara keseluruhan evaluasi kualitas output pembelajaran Bahasa Arab yang dillaksanakan di MTs DDI Seppange dapat disimpulkan termasuk pada kategori yang sangat baik.

Bertolak dari hasil interprestasi dan pembahasan terhadap temuan penelitian di atas, evaluasi pada program pembelajaran Bahasa Arab yang diselenggarakan di MTs DDI Seppange menghasilkan rata-rata skor 4,05 atau $79,40 \%$, yang berarti berdasarkan criteria standar evaluasi dapat disimpulkan termasuk pada klasifikasi dengan kategori Baik.

\section{KESIMPULAN}

Proses pembelajaran ditentukan oleh unsur atau aspek berikut; (1) Kinerja (2) Fasilitas Pembelajaran (3) Iklim (4) Sikap Siswa dan motivasi belajar siswa. Sehingga berdasarkan hasil penialian dan kategorisasi pada aspek-aspek tersebut di atas, dapat ditentukan bahwa kualitas proses pembelajaran Bahasa Arab dinilai termasuk pada kategori yang baik, Oleh karena itu, dapat ditarik kesimpulan bahwa komponen kualitas preses pembelajaran pada pelaksanaan program pembelajaran Bahasa Arab yang dilaksanakan di MTs DDI Seppange dinilai termasuk pada kategori baik.

Kelemahan pada komponen kualitas, berdasarkan hasil evaluasi kualitas, antara lain (1) masih kurangnya penguasaan strategi pembelajaran, (2) gaya mengajar guru yang kurang variatif, (3) minimnya penggunaan media dalam pembelajaran, (4) siswa kurang dilibatkan dalam pelaksanaan proses pembelajaran, (5) guru kurang menganjurkan pada siswa untuk selalu perhatian dalam mengikuti program pembelajaran, (6) guru kurang menganjurkan pada siswa untuk mencari solusi jika mengalami kendala belajar dalam usaha mencapai prestasi, dan (7) guru kurang memberikan kepercayaan kepada siswa untuk mengerjakan dan menyelesaikan tugastugas yang diberikan dengan langkah-langkah yang efektif. Hal demikian berdampak pada kualitas proses pembelajaran Bahasa Arab yang dilaksanakan di MTs DDI Seppange, walaupun rerata skor termasuk pada 
kategori baik, namun masih berada pada batas bawah, sehingga perlu diperbaiki pada beberapa aspek dari komponen kualitas proses pembelajaran tersebut, agar lebih akurat dan efektif.

Selanjutnya, pada komponen output pembelajaran, kesimpulan didasarkan pada kualitas hasil dari program pembelajaran yang ditentukan oleh terjadinya peningkatan mutu dari unsur-unsur pembentuknya, yaitu; (1) Kecakapan Akademik, terjadinya penguasaan kompetensi dasar yang dapat dimiliki siswa setelah mengikuti pembelajaran yang dibuktikan melalui nilai hasil belajar yang berhasil melewati standar KKM yang telah ditetapkan, yang pada penelitian evaluasi program pembelajaran ini dinilai termasuk pada kategori sangat baik, (2) kecakapan personal siswa, terjadinya peningkatan kecakapan atau kemampuan siswa untuk mengambil keputusan dari berbagai alternative yang dapat digunakan untuk memecahkan masalah, dinilai dengan kategori baik dan (3) kecakapan sosial siswa, terdapatnya peningkatan kecakapan yang ada pada diri siswa untuk hidup dalam masyarakat yang multi-kultur, masyarakat demokrasi dan masyarakat global yang penuh persaingan dan tantangan, setelah melalui penilaian evaluasi diperoleh hasil yang termasuk pada kategori sangat baik.

Kelemahan pada komponen kualitas output, berdasarkan hasil evaluasi, antara lain (1) kurangnya kecakapan personal siswa dalam hal mencari altematif penyelesaian masalah dengan melibatkan orang lain, siswa kurang berusaha memikirkan pengaruh/akibat dari masing-masing altematif pemecahan masalah, siswa kurang memperhitungkan keuntungan dan kerugian dari berbagai altematif pemecahan masalah yang telah dibuat. (2) minat dan bakat siswa untuk menjadi pemimpin masih kurang, dalam kegiatan kelompok rasa saling menghormati masih kurang, dan juga kurang berperan pada kegiatan kelompok. Hal demikian berdampak pada kualitas output pembelajaran Bahasa Arab yang dilaksanakan di MTs DDI Seppange, sebab meskipun rerata termasuk pada kategori baik, namun terdapat aspek 
yang masih berada pada batas bawah rerata sekor, sehingga perlu diperbaiki dan ditingkatkan terutama pada aspek kecakapan personal siswa, agar nantinya diharapkan kualitas output pembelajaran secara keseluruhan akan dapat menjadi lebih baik.

\section{DAFTAR PUSTAKA}

[1] Alberty, Harold Bernard dan Elsie J. Alberty. Reorganizing The High-School Curriculum, Third Edition. New York: The Macmillan Company, 1965.

[2] Arikunto, Suharsimi. Dasar-Dasar Evaluasi Pendidikan. Jakarta: Bumi Aksara, 2005.

[3] Arikunto, Suharsimi dan Cepy Safruddin Abdul Jabar, Evaluasi Program Pendidikan: Pedoman Teoritis Bagi Mahasiswa dan Praktisi Pendidikan. Jakarta: Bumi Aksara, 2009.

[4] Asmani. Tips Efektif Aplikasi KTSP di Sekolah. Yogjakarta: Bening, 2010.

[5] Aunurrahman. Belajar dan Pembelajaran. Bandung: Alfabeta, 2009.

Fitzpatrick, Jody L., Blaine R. Worthen, dan James R. Sanders, Program Evaluation: Alternative Approaches and Practical 
Guidelines. Boston: Person Education, 2004.

[6] Gibney, Michael J., Barrie M. Margetts, John M. Kearney dan Lenore Arab, Gizi Kesehatan Masyarakat, terjemahan Andry Hartono, Jakarta: Penerbit Buku Kedokteran EGC., 2005.

[7] Gronlund, Norman E. dan Robert L. Linn. Measurement and Evaluation in Teaching. New York: Mac Milan Publishing Company, 1990.

[8] Hamalik, Oemar. Kurikulum dan Pembelajaran. Jakarta: Bumi Aksara, 2009.

[9] Hasibuan, H. Lias. Kurikulum \& Pemikiran Pendidikan. Jakarta: GP Press, 2010.

[10] Lewis, R. Aiken. Rating Scales and Checklist: Evaluation Behavior Personality, and Attitude. New York: John Wiley \& Sons Inc, 1996.

[11] Linn, Robert L. dan Norman E. Gronlund, Measurement and Assessment in Teaching. New Jersey: Englewood Cliffs, 1995.

[12] Mulyasa, E. Kurikulum Tingkat Satuan Pendidikan: Suatu Panduan Praktis. Bandung: PT Remaja Rosdakarya, 2007.

[13] Owen, John M. Program Evaluation: Froms and Approaches. 
Sidney: Soutthwood Press, 1993.

[14] Pophan, W. James, Educational Evaluation. New Jersey: Printice Hall, Inc Englewood Cliffs, 1995.

[15] Richards, Jack C. dan Willy A. Renandya, Methodology in Language Teaching. Cambridge University Press, 2002.

[16] Roberts, Albert R. dan Gilbert J. Greene, Buku Pintar Pekerja Sosial, terjemahan Juda Damanik dan Cynthia Pattiasina, Jakarta: PT BPK Gunung Mulia, 2009.

[17] Sanjaya, Wina. Kurikulum dan Pembelajaran: Teori dan Praktek Pengembangan KTSP. Jakarta: Kencana, 2009.

[18] Spaulding, Dean T. Program Evaluatio in Practice: Core Consepts and Examples for Discussion and Analysis. San Francisco: Joseey Wiley \& Sons, Inc., 2008.

[19] Stake, Robert E. Standards-Based \& Responsive Evaluation, California: Sage Publications, 2004.

[20] Stufflebeam, Daniel L. dan Anthony J. Shinkfield, Evaluation Theory, Models, \& Applications. San Francisco: Jossey-Bass, 2007.

[21] Sukardi, H.M. Evaluasi Pendidikan: Prinsip \& Operasionalnya. 
Jakarta: Bumi Aksara, 2009.

[22] Tayibnapis, Farida Y. Evaluasi Program dan Instrumen Evaluasi: Untuk Program Pendidikan dan Penelitian. Jakarta: Rineka Cipta, 2008.

Widoyoko, S. Eko Putro. Evaluasi Program Pembelajaran.

[23] Yogyakarta: Pustaka Pelajar, 2009.

[24] Alberty, Harold Bernard dan Elsie J. Alberty. Reorganizing The High-School Curriculum, Third Edition. New York: The Macmillan Company, 1965.

[25] Husain, S.(2018). Urgensi Pembelajaran Al-Qur'an Hadist Terhadap Prestasi Belajar Peserta Didik Di Mts Nurul Ikhlas Kalapa Dua Seram Bagian Barat. al-lltizam, 3(1). 